Regular Research Article

\title{
Corporate Spheres of Responsibility: Architects, Cowboys, and Eco-Warriors in Myanmar's Oil \& Gas Industry
}

\author{
Hillary Strasser ${ }^{1, *}$ \\ 1 University of Hawaii at Manoa \\ * Correspondence author: hws@hawaii.edu
}

\begin{abstract}
Myanmar's recently opened economy is flush with incoming investment and activity. World leaders advocate that all businesses entering the country must operate in a "socially responsible manner." However, the history of corporate social responsibility (CSR) in Myanmar is undefined, contradictory, and complex. Thus, to get a handle around what it means to be "responsible," this paper investigates the collective way in which actors in the petroleum industry in Myanmar enact CSR from 1990 to 2014. The oil and gas (O\&G) industry is the most lucrative, and arguably powerful, national sector. The practice and philosophy of CSR, which originated in this industry, is now proclaimed to be the starting point for this newly charted course of responsible business in Myanmar. Yet, activists and critics maintain that CSR is an insincere PR measure of profit maximization whereby companies can conduct business as normal. I argue that CSR in the Myanmar petroleum industry is influenced by more complex factors than profit maximization or image management. CSR initiatives are sculpted by (1) the geography of petroleum extraction, (2) corporate philosophies and company national origins, and (3) type of company operations. The petroleum industry's CSR activities to date, in terms of geographic span and development targets, all fit into a spectrum of assumed spheres of corporate responsibility that have been forged by the corporate 'architects' and tempered by geographic and global forces.
\end{abstract}

Keywords: CSR; Myanmar; energy; oil and gas; philanthropy; community; responsibility; business ethics

\section{Introducing the Boundaries}

Investigating the Myanmar petroleum industry provides a dramatic picture of the underlying structures involved with resource extraction and its corresponding extreme landscapes. However, this topic also unveils an expanding social network of corporate-funded social initiatives, also known as Corporate Social Responsibility (CSR) programs. This sector does not span across the country in a geographically uniform manner. Rather, foreign and domestic companies invest, extract, and transport oil and gas in select channels out of Myanmar, predominantly for foreign consumption. Onshore production sites are scattered throughout both remote and populated locales across the country. Offshore pipelines, connecting deep-water blocks, can cross conflict zones on the borderlands and are said to exacerbate tensions. One report stated that much of the wealth generated by this industry never even enters Myanmar. A vast majority of the petroleum is purely intended for Thai and Chinese consumption (Arakan Oil Watch, 2012). The major pipelines, the Yadana and Shwe pipelines, are marred by allegations of forced relocations, forced labor, torture, inadequate compensations, and unregulated environmental exploitation.

Yet, there is a converse side to this bleak picture, and it is the social programs initiated by these very same corporations. In line with the global trend towards the deregulation of state control over corporate ventures and the commodification of development, there is a push for corporate social responsibility (CSR) programs in Myanmar to answer for unequal distribution of wealth as well as the social and ecological injustices generated by corporations. Many of these corporations initiate development programs, such as clinics, orphanages, and tree-plantings. In the 
absence of a strong NGO presence and an expansive state welfare network in the recent past (before 2014), this research demonstrates corporations profoundly shaped the social landscape of Myanmar in their select geographic milieus. CSR can be disparaged on a global scale as an empty moral endeavor, yet given Myanmar's history, such projects are significant. These corporate actions should not be dismissed, but instead scrutinized so as to better understand the ways in which companies hold themselves accountable legally, socially, and environmentally.

After decades of military rule and Western sanctions, in 2011 Myanmar embarked on ambitious political and economic reforms by transitioning to a democratic government, liberalizing resource and private sectors, and stimulating foreign investment (World Bank, 2014). Previous to this, companies operating in country were publicly and frequently accused of facilitating human rights violations. After 2011, international investment with the Union of Myanmar was enthusiastically encouraged. Leaders such as former Secretary of State Hillary Clinton declared, "Today we say to American business: invest in Burma and do it responsibly." Nobel Peace Prize Laureate, Aung San Suu Kyi, reversed her words, and now acknowledges that Total and Chevron are "responsible investors" (Nebehay). The CSR programs along the Yadana pipeline, enacted by Total, in particular are now cited a template for emulation. In years past, these same companies were vilified for engaging the very same investments in country, by the same actors.

Myanmar's government reciprocates by welcoming investors, but on the condition that companies conduct business in a socially and environmentally responsible manner (Lall, 2012). Thus, Corporate Social Responsibility (CSR) is regarded as the "key" to market entry in Myanmar. It is the "magic words on everyone's lips," (Lall, 2012).

In reference to the flood of incoming investments (across all sectors), Aung San Suu Kyi declared:

"I want good, hard-headed businessmen who are intent on making a good profit for themselves, but in a responsible way so that we also may benefit from your presence.

That means that when you talk about responsibility, it's not just CSR, it's not just social responsibility. It's political responsibility, legal responsibility. It's responsibility in a very broad sense of the word" (Ra \& Griffin, 2014).

But what does it mean to be responsible? Where exactly does this "broad sense" of the responsibly occur, and how is it created and sustained? Which players in an industry participate in responsibility, and who determines what is and is not socially responsible? What if there are no legal standards? And, is CSR really just an empty PR venture?

Defining the boundaries around responsibility has long troubled governments, corporations, and civil society. As postulated by Ferguson in The Structures of Responsibility, a defining question of our time is: "how to identify a unit of responsibility, in a fiendishly complex, multiply-layered and decidedly trans-national apparatus of harm-production?" (Ferguson, 2012).

CSR is complex because it does not have a concrete definition, and is further complicated by the intricate economic structure of companies, contractors, subcontractors, shareholders, etc. in any given economic project. Generally, CSR emerged as a self-regulating response by a corporation, in order to take responsibility for its impacts on societies and ecosystems (e.g. HSSE standards). CSR can be further used as a means to enact programs that aim to redistribute generated profits in the form of community or social programs. However in Myanmar, critics brush this as a political 'check box' without follow up, execution, legal guidelines, or worse, as a means for money laundering (in the form of donations). Globally CSR has been disregarded as an empty PR venture that ultimately serves to maximize the corporate image (Haalboom, 2012).

To get a handle around what it means to be "responsible," I investigated the collective way in which actors in the petroleum industry in Myanmar enact CSR from 1990 to 2014. The oil and gas $(O \& G)$ industry is the most lucrative, and arguably powerful, sector in the country. The practice and philosophy of CSR, which originated in this industry, is proclaimed to be the starting point for this newly charted course of responsible business in Myanmar. Yet, activists and critics maintain that CSR is an insincere PR measure of profit maximization whereby a company can conduct business as normal. 
After reviewing the activities of 19 energy companies in Myanmar and cross referencing with prominent activists, multilaterals, NGOs, academics, and specialists, I came to the conclusion that CSR in the Myanmar oil and gas industry can provide an initial insight to the above questions regarding the meaning, geography, methods, and players of "responsibility." I further argue that CSR in the Myanmar petroleum industry is influenced by more complex factors than profit maximization or image management. CSR initiatives are sculpted by (1) the geography of petroleum extraction, (2) corporate philosophies and company national origins, and (3) type of company operations. Details of CSR initiatives are shaped by individual corporate logics. The boundaries around these corporate spheres of responsibility have been orchestrated by a range of actors, institutions, and forces. This has resulted in an expansive network of responsibility in terms of geographic coverage and also in terms of development targets. In short, CSR and the understanding of "responsibility"' is complex. Theses nuances cannot be wholly brushed off as an empty-hearted PR measure.

To support my arguments, I first provide some theoretical context for CSR and the social context of Myanmar's industry. I then provide some context to the political nature of petroleum and then to extreme operations. After this, I introduce the situation that is the nexus of CSR, Myanmar, and Oil \& Gas. Following this, I summarize my methods. Next, I present my research findings. In this section I describe the three primary factors that shape CSR programs, followed by individualized corporate reasons. First, I investigate the geographic span of CSR to illustrate how the geography of an operation affects where CSR programs are created. I provide details and justifications for programs initiated by offshore and onshore operators. The boundaries around CSR programs are also constrained by company budgets. Next, I show how the national origins and philosophy of a company can affect CSR implementation. And lastly, I explore the uneven obligations of CSR imposed upon different types of companies. Generally, upstream operators are expected to enact CSR, while the contractors, which are integral to any operation, are not expected to engage in CSR. Although there are specific instances which defy these generalizations, this paper provides an insight into overall logic of CSR in the industry.

Dissecting where and how companies enact CSR gives insight to the emerging shape of responsibility in this sector and country. Given the impact corporations have on our earth and society, this is deserved of close attention. This, in turn, provides a window into the ways in which companies now demonstrate 'social responsibility' in a post-colonial, capitalistic, global political-economic framework.

\section{Theoretical Framework}

\subsection{The Context of CSR}

Corporate Social Responsibility is a business initiative where corporations strive to mitigate environmental and social impacts (Occupational Health and Safety standards, etc.), to abide by a set of regulations and standards (using the Equator Principles or IFC standards), as well as to improve the public sphere (in the form of community programs). In the absence of a global legal entity to hold corporations accountable for environmental negligence, humanitarian abuses, and a deregulated economic legal framework which enables profit maximization at the cost of ecosystems and communities, CSR emerged as a self-regulating corporate response to public and stakeholder demands for more responsible operations and actions.

At this same time, progressive critics of CSR view such initiatives as "market led and privatized forms of governance associated with neoliberal globalization" (Barkan, 2013). It has been, and continues to be, cast off as both "disingenuous" and "ineffective" in global and local contexts (Haalboom, 2012). All of these claims are broad postulations that ignore specific corporate activities and geographic contexts which should deserve closer attention.

CSR has been "undergoing a definitional evolution" since the 1940s and has crystallized into a form of self-regulated, voluntary investment standards in reaction to increased public concern about successive deregulations in the 1990s (Shamir, 2010). It aims to placate the legal and moral problems that companies encounter when investing in states without strict regulations. CSR can go 
beyond internal compliance: it has evolved as a venue for redistributing corporate wealth in the form of welfare ('CSR programs').

In spite of its imprecise definition, CSR is now promoted by societies, governments, and corporations. Organizations such as the World Bank, United Nations, and Organization of Economic Co-operation and Development (OECD) have endorsed, promoted, and systemized CSR programs (Lee, 2008). Most Fortune 500 firms now actively promote CSR in their annual reports, and the Conference Board reported that $90 \%$ of corporate managers state that their companies take CSR "very seriously" (Lee, 2008). The CSR initiative has become an integral part of businesses, both from an economic and social standpoint. However, the financial benefits for the company and its shareholders remain inconclusive and it still is not clearly defined (Lee, 2008).

This broad understanding leaves "CSR" very difficult to recognize. As a framework, I conceptualize CSR as a practice that comes about in two distinct forms:

- First, CSR addresses the lack of government regulations upon corporate activities. It can be an internal governance practice that aims to ensure company operations adhere to environmental standards, pay taxes, abide by international regulations, and protect human and labour rights. The internal aspects of CSR can be understood as strong Human Resources and HSSE policies and robust codes of conduct so that companies can still perform to an international standard, even in a deregulated or unregulated legal context. This can also include (and should) grievance mechanisms, as this is an integral part to a company ensuring its social license to operate.

- Second, CSR can aim to redistribute the generated wealth in the form of corporate philanthropy. This is the external community form of CSR which is manifested in community initiatives and social programs. These programs are not part of the company's core extractive operations and, at times, can appear to be irrelevant to a company's philosophy. Confusingly enough, sometimes these community initiatives can be any combination of social programs in areas of company operations and/or social programs with no geographic or company link.

The external community aspect of CSR incurs divergent positions. Some maintain it is not a company's responsibility to drive social change (as this is an impingement on the state's duty), and the company should instead focus on paying taxes, abiding by environmental standards, and instituting community grievance mechanisms only. Some claim that because 'failed states' are unable to sufficiently collect taxes in order to institute welfare programs, companies have an obligation (and responsibility) to fill the void and enact community projects.

Most studies to date overemphasize the business side of CSR rather than provide evidence of social changes. Corporations are indispensable members of our society; both society and corporations are have profound behavioral influences on the other. In her study of the mining company Anglo America, Rajak claims that anthropologists study CSR by looking at the "intended targets, rather than the architects, of these ethical regimes" (Rajak, 2011). The media, NGO reports, and academic accounts usually focus on the beneficiaries of CSR rather than the architects of the CSR industry.

This account provides an overview to the complex, but systematic, logic behind the "units of responsibility" as justified by the CSR "architects" of the Myanmar petroleum sector. Given that it is difficult to follow up on a company's tax record, application of environmental standards, guarantee of labour protection, and other internal CSR components, this account focuses on the external CSR programs and grievance mechanisms orchestrated by the architects in this deregulated, frontier sector.

\subsection{Oil \& Society in Myanmar}

During the 1980's Western divestment in Myanmar, it became an ethical obligation to shun investment as an effort to encourage respect for human rights. The impact of these sanctions, although severe, was tempered by reinforced investment by Asian companies - especially in extractive sectors ( $O \& G$ and mining in particular). Corporations that remained in Myanmar have been accused of serious malpractices including reckless ecological destruction, the blatant 
disregard for human rights, as well as the enablement of the Myanmar army. Western oil giants Total and Chevron remained at this time.

There is a centralized component to the energy sector. To invest, every foreign and local company must sign contracts ${ }^{1}$ with the state-run Myanmar Oil and Gas Enterprise (MOGE) and afterwards may explore and extract petroleum. Myanmar is emerging as a key producer of natural gas, with more than 60 global O\&G companies participating in exploration (Oxford Business Group, 2014). Over the past decade, the government auctioned onshore and offshore blocks for companies to explore for petroleum. The entire continental shelf, as well as vast regions on land, were sold to the highest bidders in blind auctions.

The Myanmar economy is "one of the least developed in the world;" it suffers from decades of stagnation, mismanagement, and isolation (Myanmar Profile, 2014). Transparency International in 2010 ranked Myanmar as the second most corrupt state in the world (just beating out Somalia as dead last). However in 2014, Myanmar moved up eighteen slots to share the $156^{\text {th }}$ position with Cambodia out of 175 ranked countries (Transparency International, 2014). Compared with other Southeast Asian neighbors, Myanmar lagged far behind in terms of companies' ability to secure electricity, permits, licenses, and the average times to set up businesses (Temphairojana, 2013).

Although accurate statistics are difficult at best to come by, Myanmar has consistently ranked at the bottom of most socio-economic indicators. In stark contrast to the revenue statistics generated from the petroleum industry, Myanmar is one of the poorest countries in East Asia and the Pacific. The estimated GDP per capita for $2012 / 2013$ is $\$ 868$. Thirty-two percent of children under the age of five suffer from malnutrition, and access to drinking water is limited in many regions. Current power infrastructures only meet half of the current demand. ${ }^{2}$ Only $30 \%$ of the population is connected to the grid, yet $25 \%$ of Thailand's electricity comes from Myanmar (U.S. Campaign for Burma, 2012).The consumption of electricity in Myanmar is one of the lowest in the world: 20 times less than the global average (World Bank, 2014).

Myanmar's GDP expanded $8.7 \%$ in 2014 from the previous year; this trend is expected to continue (Global Finance, 2015). The O\&G sector has been the single largest source of foreign exchange in Myanmar for decades. Foreign direct investment (FDI) in the O\&G sector amounted to $\$ 15.18$ billion as of October 2014. This accounts for over $30 \%$ of the total FDI (the power sector comes in at a close second) (Aye Myat, 2015). The sale of natural gas alone was expected to bring an estimated $\$ 29$ billion over the next thirty years.

\subsection{The Political Nature of Petroleum ${ }^{3}$}

Petroleum extraction is a highly controversial industry. Companies have engaged in unscrupulous business practices resulting in severe social and environmental costs. High profile disasters, from oil spills to human rights abuses, fuel public outcry and enact harsh criticism from the media, NGOs, and government. Such initiatives have resulted in significant and positive changes in business practices. In reaction, oil majors have instituted strict safety measures and turned to CSR as a means to counter the negative public sentiments, build reputational capital, and ultimately achieve legitimacy (Du \& Vieira, 2012). Currently oil majors spend hundreds of millions of dollars in an effort to improve their safety record, reduce emissions, and to alter the perception of their unsustainable practices (Bridge \& Le Billon, 2013). However, CSR in this industry most especially has been criticized as a façade which allows oil corporations to continue with business as usual (Godfrey, 2009). Bridge and Le Billion note that CSR cannot address the broader economic and governance issues which are associated with corporate injustices.

\footnotetext{
${ }^{1}$ Public Sharing Contracts, PSC

${ }^{2}$ As a recent Mizzima article details, the government has promised access to electricity for $50 \%$ of the population by 2020 . Historically, most electricity has been siphoned to the major cities rather than distributed across rural regions (Mizzima News).

${ }^{3}$ Terms such as 'Big Oil' and 'Oil majors' are used to group the world's largest publically owned oil corporations; Total and Chevron are amongst the six largest, and are also known as 'supermajors.'
} 
The geologic and geographic properties of petroleum make it a deeply political resource (Mitchell, 2013). The fossil fuel network with its corridors and venues of investment are marked by a concentration of wealth and power. Petroleum is not distributed evenly around the world because the necessary geologic conditions are not uniform. Extraction and processing requires a much smaller work force (as compared to our previous major global fuel source, coal). Further, the liquid form of petroleum allows for pipeline transportation as opposed to railway transport manually loaded into carts. Such physical properties have diminished the power of local workers, who normally would control the sites of the energy production (Mitchell, 2013).

In Fuelling War, LeBillion examines the paradox of resource rich states plagued by conflict and poverty. Significant portions of resource rich countries are subject to poverty, harsh conditions, and blatant inequality. Strategic resources, such as oil, attract foreign investors; yet, the physical properties of oil combined with the preexisting social and political structures do not distribute the generated wealth in an equal manner. With increasing demand for petroleum the 'frontier' of extraction has shifted to the extreme. This shift occurs both in a physical sense, such as Arctic and ultra-deep water exploration, and in a social sense, such as investing in states with controversial governance systems like the D.R. Congo and Equatorial Guinea. The social nature of this political resource is augmented in such unconventional contexts (Bridge \& Le Billon, 2013). Myanmar can be considered an extreme context as it is the world's newest frontier for investment, it is undergoing rapid political and social transformations, and there are minimal regulations for ongoing accelerating extraction.

\subsection{Extreme Operations, Petroleum, \& Responsibility}

CSR, as a business practice and concept, has been globally accepted by mining and petroleum corporations. These industries in particular can be notorious for environmental negligence (Arakan Oil Watch, 2012) (Doe v. Unocal Case History, 2012) (Mitchell, 2013). Extraction can occur in "extreme contexts" such as unstable and militarized governments (Dellinger, 2009) or in socially violent environments (Peluso \& Watts, 2001).

Commonly, these regions have little regulatory oversight over private investments, and they lack robust state welfare systems for local citizens. The generated wealth is channeled into the hands of a few (Bridge \& Le Billon, 2013). In such instances, companies are criticized for engaging in such a socially violent landscape and for capitalizing on the absence of regulations. States are criticized for not redistributing the generated resource wealth to its citizens.

There are methods to hold companies accountable in unregulated legal contexts, and Myanmar boasts a pivotal legal example. In the 1990's, pressure from EarthRights International's legal front accumulated in the court case Doe v. Unocal, where Myanmar farmers sued the multinational corporation Unocal (now acquired by Chevron) for the violations of human rights in the construction of the Yadana pipeline (Shamir, 2010). This set the precedent for plaintiffs to use the Alien Tort Claims Act ${ }^{4}$ as a way to enforce the respect for human rights through the American federal court system.

Operating and investing in such compromising situations is highly controversial. CSR, in the form of corporate voluntary self-governance and corporate funded welfare programs, aims to remedy these criticisms. Accordingly, investments in "extreme contexts" or "failed states" in particular demonstrate a clear need for (1) corporate self-regulation and (2) a form of wealth distribution for social programs. Given the vague or absence of government oversight and inadequate welfare programs, it is now expected that companies both (1) "self-regulate" and (2) "give back." Thus CSR has become an integral facet to private sector engagement with resource

\footnotetext{
${ }^{4}$ The Alien Tort Claims Act (also known as the Alien Tort Statute) is a section in the U.S. Code which ensures, "the district courts shall have original jurisdiction of any civil action by an alien for a tort only, committed in violation of the law of nations or a treaty of the United States." U.S. law has interpreted this Act as a means for foreign citizens to seek justice in U.S. courts for human rights violations committed outside the boundaries of the U.S.
} 
extraction in such contexts, as illustrated by cases from Rio Tinto $^{5}$ in Bougainville, PNG (Gilberthorpe \& Banks, 2012) to Newmont in Indonesia (Welker, 2014).

While CSR is strongly encouraged in Myanmar for all incoming companies, there is no official definition of CSR from the central government. The Myanmar Investment Commission (MIC) has no specific guidelines, and there is no legal structure to enact $\operatorname{CSR}^{6}$. Companies interpret CSR as anything from charitable donations to robust health and safety (HSE) procedures.

Such indirection is not uncommon. Globally, there is no sovereign body to govern the development of CSR, and the conditions outlined by the United Nations are ambiguous. A U.N. Brief acknowledged that a detailed definition remains a "vexed issue." At the very least, CSR means a business must abide by local legal obligations and that they "do no harm." At best, investments will support "societal goals" and "sustainable development." In short, CSR is up for interpretation. In an interview with a director of an O\&G services company, he exclaimed "it's like the Wild West of CSR!" thus indicating the panoply of "responsible" corporate actions, understandings, and enactments.

\subsection{CSR in Myanmar's Oil \& Gas Industry: 'the Wild West of CSR'}

Myanmar's first CSR programs were initiated in the 1990's by Total, a French multinational petroleum corporation which operates the Yadana Project. While these flagship programs were created, Total and Unocal (now Chevron) were brought to court in Belgium and the US, respectively, for facilitating the violent practices of the Myanmar army while constructing the pipelines. These socio-economic projects now support 50,000 people across 25 villages.

Since then, CSR initiatives by international and domestic oil companies have proliferated. Many are now found in locales that are both proximate and distant to company operations. They range from addressing a tale of hardship to putting a city on the electrical grid. Levels of corporate commitment and extent vary; others are largely uncoordinated, even among partners. Many could be confused with an aid project initiated by NGOs, missionaries, multilateral institutions, and the like. A number of CSR programs appear to be philanthropic acts with little business rationale or geographic relationship. Many projects have been confused with aspects of Buddhist merit-making or as a donation. Environmental groups criticize oil-funded social programs as 'Boutique CSR' which ultimately serves a company's image or profit maximization. Studies on CSR, Myanmar, and Oil \& Gas include research conducted by Holliday and Black,

Many CSR programs focus on education, health care, and the environment. They are found in regions far from petroleum operations, while others are in close proximity to offshore pipelines. Examples include scholarship opportunities, tree plantings, funding for festivals, and medical clinics. Although there are multiple partners and contractors for any given operation, only select companies partake in CSR. Many programs are not detailed on company websites, while other companies overemphasize some of their CSR activities, according to research analysts.

Select companies have a particular focus for their development programs. For example, Parami focuses on monastic education; General Electric works on legal reform, energy access, and maternal health; operators from Daewoo to Petronas will provide emergency relief and enact expansive networks; while other companies argue that it is not the company's place to subsidize aid programs. Some companies, such as Total, CNPC, and Petronas have initiated programs across the country in addition to projects in their area of operations. There does not appear to be an immediate rationale to explain the geographic diversity and variety of development targets. One

\footnotetext{
${ }^{5}$ Rio Tinto extracted copper and gold from the island of Bougainville, PNG. Extreme social tensions arose at the Panguan mine from environmental degradation, which culminated in militant riots, PNG troop deployment, and later a civil war (the 'Coconut Revolution'). There is recent talk of welcoming the copper mine back to Panguan on the condition that the company implements a thorough CSR initiative.

${ }^{6}$ Companies in Myanmar will pursue a Social License to Operate (SLO), but may shy away from an internationally accepted CSR program, as such goes beyond its legal requirements Invalid source specified.. A SLO is not a legally binding agreement, but it can be built upon through community acceptance.
} 
gains a greater appreciation of the scale of petroleum investments (and developments) in the face of such an astounding display of programs.

Weaving together the "units of responsibility" as understood by the architects of the Myanmar petroleum industry provide unexpected results ${ }^{7}$. CSR aims to placate social and ecological ills generated by the industry. However, in the absence of specific laws and in the face of conflicting expectations from local and international actors, petroleum corporations have assumed (1) distinct geographic spheres and (2) particular arenas of development to exhibit their responsibility. At first glance, the network of CSR cases does not appear to have a systemized logic.

\section{Methodology \& Fieldwork Overview}

I spent three months during the summer of 2014 in Myanmar and Thailand conducting fieldwork for this project. The primary field site was Yangon, Myanmar. It is the economic capital and the office location for petroleum companies and for organizations that monitor and conduct research on extractive industries. I made a trip to Chiang Mai, Thailand to interview environmental NGOs whose offices are not yet welcome in Myanmar. In total, I conducted 26 formal interviews and three informal interviews.

To conduct a sector wide survey, this analysis evaluates the CSR activity of 19 energy companies (15 of which I interviewed). This includes: onshore operators and partners such as MOGE $^{8}, \mathrm{MPRL}^{9}, \mathrm{CJSC}$ Nobel Oil ${ }^{10}$, GoldPetrol ${ }^{11}$, and Parami Energy Group ${ }^{12}$; offshore operators and partners such as Petronas ${ }^{13}$, Daewoo ${ }^{14}$, CNPC $^{15}$, Chinnery Assets ${ }^{16}$, Total $^{17}$, Chevron $^{18}$, PTTEP $^{19}$, $\mathrm{CNOOC}^{20}$ and KT Energy ${ }^{21}$; and oilfield service companies such as Halliburton ${ }^{22}$, Weatherford ${ }^{23}$,

7 To date, there have only been a few published accounts of CSR in association with Myanmar petroleum industry in the social sciences. Both have focused on Total's Yadana Pipeline (Black, 2009) (Holliday, 2005).

${ }^{8}$ A state-owned company, MOGE is responsible for the exploration, development and gas transit as well as the onshore, shallow water and deep water block terms. The Myanma Petrochemical Enterprise (MPE) controls the processing of petroleum and the Myanma Petroleum Products Enterprise (MPPE) deals with the distribution and sales of petroleum products.

${ }^{9}$ A privately owned company, registered in the British Virgin Islands with its regional head office located in Singapore but run by Myanmar nationals.

${ }^{10}$ An independent oil and gas holding company from Russia that is $50 \%$ foreign owned (China Investment Corporation has a $45 \%$ stake).

${ }^{11}$ A foreign joint venture and is majority owned by Singaporean conglomerate Interra

12 Myanmar group of companies which provides offshore and onshore oil and gas field-services, founded in 2004

${ }^{13}$ Malaysian government owned corporation, subsidiary of Petroliam Nasional Berhad (Petronas).

14 South Korea's largest trading company, founded in 1967. It is involved in steel, chemicals, metal, machinery, and resource development in foreign countries

${ }^{15}$ China National Petroleum Corporation: Chinese state-owned oil and gas corporations. Largest integrated energy company in China.

${ }^{16}$ Chinnery Assets Limited operates as a subsidiary of CNPC Hong Kong Ltd. A joint venture formed by two subsidiaries of CNPC, making this a state-controlled company.

${ }^{17}$ A French multi-national integrated oil and gas company, Total S. A. is one of the six 'supermajor' oil companies in the world. It operates in upstream, midstream, and downstream oil and gas and is a large scale chemical manufacturer. It was founded in 1924.

${ }^{18}$ Chevron Corporation is a multinational (American) energy corporation, engaged in upstream, midstream, and downstream. One of the world's largest companies. Acquired Unocal after the Doe v. Unocal court case.

19 PTT Public Company, Thai state-owned oil and gas company.

${ }^{20}$ China National Offshore Oil Company: National oil company from China

${ }^{21}$ Private, family owned operations in Myanmar. KT Energy focuses on the oil and gas industry within the KT Group

${ }^{22}$ American multinational corporation, one of the largest oilfield service companies.

${ }^{23}$ One of the largest oilfield service companies, founded in Texas in 1941. 
Schlumberger ${ }^{24}$, Punj Lloyd ${ }^{25}$, and SMART Technical Services ${ }^{26}$. I include General Electric in my analysis because this power company spearheads CSR initiatives.

The petroleum industry is expansive and intricate; by no means is one company the main driver of any one operation. By asking corporations where their responsibilities lie, I attempt to elucidate the rationales behind these purveyors of CSR.

I compared the corporate information with interviews and documents from related researchers, monitoring agencies, and journalists. I interviewed personnel from the World Bank, Extractive Industry Transparency Initiative ${ }^{27}$, the Asia Development Bank, the Centre for Business and Human Rights, the non-profit Spectrum ${ }^{28}$, Revenue Watch, the first American law firm in Myanmar (HRH\&M), Global Witness, and the Myanmar Center for Responsible Business (MCRB).

I interviewed staff and/or program managers from several activist groups: EarthRights International (ERI), Arakan Oil Watch (AOW), and the Shwe Gas Movement (SGM). These interviews provided some illuminating accounts of petroleum extraction that are not told in the CSR pamphlets or company websites. Furthermore, I conducted informal interviews with three professors who specialize in Myanmar affairs.

These interviews were necessary to better assess the contradictions and paradoxes discovered in my research topic. Although my interviews were open ended, I asked my O\&G participants to elaborate on:

(1) who conducted research for the company's CSR programs,

(2) where are the CSR programs,

(3) how are these programs received.

I asked all of my participants to describe:

(4) what is the difference between a community CSR program and a similar type of program funded and implemented by an NGO, aid organization, or the state, and

(5) the limitations of CSR, how it could be improved, and how corporate accountability is shaping up in Myanmar.

I readily volunteered anonymity for those who participated in my research project, and this played a pivotal role in being granted access. Many participants did not want to be quoted directly, although a few were happy to be cited. To be consistent, I do not identify any individuals by name for either direct quotes or general insights. Instead I describe my sources as "a CSR manager," "project manager of an NGO," "oilfield service director," and the like. Instead of using quotes with compromising information, I used confidential material as a frame of reference to better understand the ways in which CSR has materialized.

\section{Research Findings: The Logic of the Architects}

From my interviews and research on the CSR case studies, I came to the understanding that there are three primary factors that drive how, what kind of, and where CSR programs are implemented. First, the geographic location of company operations determines where many CSR programs are initiated. Offshore operators, onshore operators, and contractors have select geographic spheres of operations and thus rationalized corresponding zones of CSR. Second, the national origins and individual corporate philosophies can determine the type of CSR activity. And third, the type of company operation (such as the operator vs. the contractor for an offshore pipeline) has a clear impact on CSR initiatives.

In addition to these three main factors, specific enactments of CSR are supported by an assortment of corporate logics. Some companies adhere to a specific corporate philosophy that is

\footnotetext{
${ }^{24}$ The world's largest oilfield service company. Founded in 1926 by French brothers, headquarters now in Houston TX. Publicly-listed company.

${ }^{25}$ Construction and engineering service group for energy operations, based in New Delhi.

${ }^{26}$ Oil and Gas service provider to foreign and local customers in Myanmar, founded in 1994.

${ }^{27} \mathrm{EITI}$ is a global coalition of governments, companies, and civil society working together to improve openness and accountable management of revenues from natural resources (EITI, 2014).

${ }^{28}$ a nonprofit dedicated to the Sustainable Development Knowledge network
} 
reflected in their campaigns around the world. Others have a "business case" for CSR, some CSR programs are shaped by the personal ethics of an individual within a company, and other companies respond to community requests. These logics, combined with the three main drivers, are the impetus for CSR programs.

\subsection{The Geographic Span of CSR}

Although petroleum is a national resource owned by states, as the resource is literally embedded in a state's territory, there is a complex diversity of actors involved in the industry. Petroleum is understood to be part of the 'body' of the state, thus evoking charged policy decisions (Bridge \& Le Billon, 2013). Yet it is companies, not states, which explore, transport, and produce petroleum. There is a distinction between state owned (national) oil companies (NOCs) and international oil companies (IOCS). Companies are further divided into upstream (exploration for petroleum), midstream (transportation of the oil and gas), and downstream (the refining process). Contractors and sub-contractors provide drilling services, technical support, catering, security details, etc., so that operations are even possible. As this resource is only found in certain environments, it requires extensive infrastructure to be extracted out from the 'body' of the state. This involves coordination from operators, partners, contractors, and sub-contractors. Oilfield service companies, such as Halliburton and Schlumberger, are essential as they are contracted out for all projects. Even though there are dozens of corporations involved in any one project, my research indicates that most CSR initiatives are shouldered by the upstream operating companies.

\subsubsection{Offshore Operators}

All offshore operators must create CSR programs in geographic proximity to their zones of operations, per agreements in their public sharing contract (PSC) with MOGE. Given that offshore extraction occurs miles at sea with no communities to speak of, project operators must perform CSR on land. This has come to mean that operators (such as Total, Daewoo, etc. ${ }^{29}$ ) create development programs in the vicinity of their oil terminal and/or pipeline (Yadana, Yetagun, Shwe pipelines respectively). This expectation has encouraged CSR programs that are proximate to petroleum operations. I regard this as a direct geographic rationale for community programs, as the recipients are those that would most likely bear any externalities from these operations. Although these companies have enacted welfare programs in the immediate vicinity of their respective oil terminals and pipelines, there are no clear definitions of exactly how far out and exactly who constitutes the surrounding communities. Further, these programs do not span contiguous space along the offshore pipelines, but rather they occur in select enclaves. Contractors and sub-contractors, although indispensable to oil projects, are not obliged to contribute funding or assist in CSR efforts.

Pipeline construction from oil terminals have been shown to cause negative environmental and social impacts, as illustrated by the violations arising from the Yadana and Shwe pipeline constructions (Arakan Oil Watch, 2012) (EarthRights, 2004) (Doe v. Unocal Case History, 2012). However, according to an onshore CSR manager, once the pipeline is established it does not cause as severe an impact as an onshore operation because the extraction occurs at sea, miles from any communities. This assertion was confirmed by several CSR managers of offshore and onshore sites. Even so, many company representatives expressed the desire to give back some of the wealth. One manager in particular, "[feels] that the country needs help," and this company has subsequently created extensive regional projects.

\footnotetext{
${ }^{29}$ According to several difference sources, Chevron has created a CSR program which funds underprivileged youths in the Tanintharyi region. I was unable to secure an interview with Chevron, and there is no information about this program online. However, I include Chevron's community program within the analysis of offshore operators because Chevron inherited many of the community issues passed down from the Unocal law suit, and currently owns $28.3 \%$ of the Yadana pipeline.
} 
None of the interviewed companies, except Daewoo, provided specific boundaries for their zone of responsibility. In fact, Petronas and Total explained that they are expanding their programs to include other villages beyond the region immediately surrounding the pipeline (the pipelines have not been extended). They also fund programs across the country. For instance, Petronas created several education funds and contributes to a wildlife reserve outside Yangon, and Total has funded programs ranging from musical concerts in Yangon to clinics in several states across the country. But none of these acts of philanthropy have any geographic link to their operations.

Per their PSC, Total, Petronas, and PTTEP are obliged to create community programs along the Yadana, Yetagun, and Zawtika parallel pipelines. I received conflicting reports on the coordination of these shared CSR efforts. From my interviews, it became apparent that the other companies tend to piggyback onto Total's network of CSR programs. All partners (such as Nippon JX, Chevron, and MOGE) will contribute funding, but Total is the primary executor. Total's and Petronas' programs have a long history in Myanmar, since the early 1990's, and were recently applauded as the model of CSR by none other than Aung San Suu Kyi. Researchers described Total and Petronas' social work along the pipelines as "comprehensive." It is unclear how far out, in terms of communities and distance, social responsibility extends, as there are several conflicting geographic delineations.

Daewoo defines its geographic span of responsibility solely in the region immediately surrounding the terminal on Kyauk Phyu Island. Given that Daewoo is the current operator of the entire Shwe Project, with a $51 \%$ stake, ${ }^{30}$ I had assumed this meant Daewoo is responsible for the geographic length of the Shwe project (from Kyauk Phyu oil terminal and Sino-Myanmar parallel pipelines to the refinery in Kunming). However, two Chinese companies are responsible for the social programs and community compensations along the pipelines. Daewoo does not regard itself as responsible for the $O \& G$ transport or social programs beyond the oil meters on the Kyauk Phyu. Accordingly, it has built hospitals and schools on the island. Daewoo maintains it will consult with all partners before enacting a social program (usually in the form of a donation ceremony, or the construction of a hospital/school). Other partners contribute funding towards programs, but I was not given a clear number, estimate, or method for these transactions. Like Total and Petronas, Daewoo also funds programs that have no geographic link to its Shwe operation.

Two Chinese companies, SEAGP and SEACOP, share the responsibility to enact social programs along the Shwe pipelines (Sino-Myanmar pipelines). No other company was able to provide exact information about the CSR programs from these two companies, and I was unable to find updated contact information to speak with company representatives. Even some of their partners "did not know much detail" about the companies or their CSR programs.

I interviewed an Asian company that operates several blocks in the Bay of Bengal. It regarded CSR as more of a function of human resources (HR) and benefits for company employees in Yangon. This company, similar to others extracting from the Myanmar coast, does not have fully developed community CSR programs. Like Daewoo and the two companies along the Sino-Myanmar pipelines, it would construct buildings upon request - such as a school or a hospital. Both CNPC and CNOOC enact programs and constructions that are proximate to their operations.

In conclusion, offshore operators such as Total, Chevron, Petronas, PTTEP, CNPC, CNOOC, and Daewoo are obliged to enact programs close to their zones of operation. This creates a geographic link with respect to their obligatory community programs, or rather a zone of responsibility. Community programs are created either along operational pipelines, or at the site of an oil terminal. Although the offshore rigs are far from the communities, the onshore pipelines run through communities and paddy fields. The most destructive and intrusive aspect of petroleum extraction occurs at sea - miles from communities. None of the companies, except one, delineated their regional zone of responsibility in specific terms. Most used vague terms to demarcate their arena for CSR. Although aid and welfare, broadly speaking, are considered to be beneficial aspects

${ }^{30}$ Other partners in the Shwe project include India's ONGC Videsh (17\%), India's GAIL (8.5\%), Korea Gas (8.5\%), and MOGE (15\%). 
of a company, it is a highly political decision as to who does and does not receive such benefits. More ethnographic research is needed to fully appreciate how oil aid is received in these zones.

An offshore CSR manager acknowledged, "When we are talking about [responsibility], the onshore pipeline doesn't really affect the community. But we will affect some fishermen when we work offshore." She went on to explain that some community members on land were affected by the pipeline, but this was not significant. Even those working for monitoring agencies have mentioned the positive impacts of select offshore CSR programs. Essentially, after the pipeline is constructed there no longer is a strong need to create CSR programs that would mitigate social tensions, but there are public and government pressures to enact land based social programs. A CSR representative from an onshore company mentioned there were "less social issues to deal with" for the offshore CSR managers. She elaborated, "it is easy to engage with someone who isn't affected [as they are] by living next to a [onshore] well."

\subsubsection{Onshore Operators}

Counter intuitively, there is not a direct geographic link for onshore operator CSR programs. Until 2012, onshore operators were discouraged by the government from creating external CSR programs in communities adjacent to or living in their onshore blocks. This is surprising because onshore projects are invasive by nature of the extraction - many of these sites occur very close to village communities or functioning rice paddies. They operate dangerous wells, which need close monitoring and security. One would expect, given the intense nature of petroleum extraction, that there would be encouragement for a type of ameliorative CSR plan in the immediate vicinity.

Evidently MOGE did not permit onshore operators to create social programs in the same areas of extraction for fear of community riots and protests. An onshore CSR manager explained the logic: since communities are much more drastically affected by onshore operations (there is an open pit/well continuously pumping out gas or oil adjacent to rice paddies and communities), it was best to remain entirely disengaged. If there was engagement, it was in the form of a building construction, but not a sustained social program. This finding was confirmed by CSR managers, engineers, and company directors. However, MOGE is now open to active community engagement in onshore sites.

Such a change in mindset takes time. As of 2012, MPRL has made efforts to create CSR programs in the Mann field. In the meantime and in accordance with the government instructions, onshore operators have engaged in a wide variety of CSR initiatives that are distant from operations. Parami ${ }^{31}$ has created CSR programs in Shan and Kayin states. These projects are not in proximity to its operations, which are west of Yangon.

KT Energy, a Myanmar O\&G company and joint operator with Russian company JSOC Bashneft, created the nonprofit foundation KT Care to manage all philanthropic activities. Its activities span the country and ranges from emergency response to capacity building. It created programs in the delta region, Rakhine state, as well as around Yangon. Many of these programs are community oriented but not in relation to the communities where KT Energy operates. The KT Care staff I interviewed were unaware of KT Energy's partners or of its locales of operation. This instance of CSR in particular highlights the blending of the actors involved in corporate spending on development projects.

MOGE does not have any information about CSR programs online and I was unable to secure an interview with a current MOGE employee. One CSR manager remarked that MOGE would occasionally build a school or pave a road at the village's request. But, as she emphasized, this is clearly nothing official or "well-planned." Nobel Oil has no information online of any specific programs in Myanmar and does not create CSR programs, although it does engage in ad hoc type of philanthropies. I was unable to find any information about GoldPetrol's CSR activity and was unable to make contact with the company. This is unfortunate because GoldPetrol was one of the

\footnotetext{
${ }^{31}$ Both MPRL and Parami have received positive reviews from the Myanmar Center for Responsible Business (MCRB) for their efforts on increased internet transparency, and both responded to Global Witness' request for benefit sharing information.
} 
four seats on the multi-stakeholder group board for the Extractive Industry Transparency Initiative (EITI).

In sum, onshore operators generally create CSR programs without geographic rational, which makes sense given the historical context. MCRB's reviews indicated that companies such as Total, Parami, and MPRL are the leaders in setting the precedents for increasing transparency and/or creating social programs. This evolution is tempered by MOGE's shortcomings in the CSR effort. As the overseer of all petroleum operations, the default local partner of international corporations, and the centralizing authority for approving CSR programs, MOGE should be spearheading CSR by logic. Since CSR, as a business concept, is still in its initial stages in Myanmar, there is opportunity and potential for MOGE to take the initiative and for onshore operators to install CSR programs within their onshore blocks, in addition to the randomly placed philanthropies.

\subsubsection{Extraction without Development}

A significant number of companies in the petroleum industry do not enact community CSR programs, do not have information about CSR on their websites, do not have websites, have conflicting contact information, and seem to make no effort to jump onto the new CSR bandwagon. Many of these companies include contractors and sub-contractors to an oil or gas project who have no CSR obligations. This is not, legally speaking, unfitting because only the operator must assume programs. However, contractors, sub-contractors, catering services, security details, etc. are the fuel of the petroleum industry. Leaving these constituents out of the CSR picture greatly narrows the sphere of responsibility in this sector. This also highlights the uneven obligations of CSR imposed on companies in the industry.

Several of my interviewees informed me that their company just did not perform CSR. Many were frank about the shortcomings of their CSR initiatives, and on multiple occasions I was told their CSR was "not enough" by company representatives from Asian and Western companies. One representative emphasized that I should not praise its CSR because, despite the suggestions of its pamphlets, the company never did any CSR in Myanmar.

The industry transforms social and ecological landscapes; many companies are accused of malpractice. Operations create roads, pipelines, wells, and bridges. Onshore extraction consists of open wells with vast tracts of jungle and agricultural lands removed. Offshore projects build pipelines that transport resources from the 'body' of the state to foreign markets. Communities are given compensations, but there is conflicting evidence about the success and implementation of the compensations (Arakan Oil Watch, 2012) (CNPC, 2012).

\subsection{Corporate Logic and External Forces upon CSR}

A spectrum of forces drive the specifics of CSR programs. This includes the global narratives of a company's philosophy, the pressure from internationally acclaimed politicians and company stakeholders, the personal ethics of an individual in the company, and the requests from local communities. The justification of a "business case" for CSR can be but one of many components in the CSR undertaking. The previous section examined the rationale behind the geographic location of CSR. This section explores the specifics of CSR programs and discusses the implications of company national origins.

\subsubsection{A Spectrum of Influences}

The principles of individuals within a company can be a profound shaper of community programs. For instance, Parami focuses on monastic education, a traditional aspect of Myanmar social fabric, and environmental programs like tree plantings. Its CSR manager emphasized the importance of collaborating with local governments. The company has detailed information about all CSR activities on its website, has public endorsements of the importance of CSR, and readily volunteered to coordinate a research visit to a community program. As for a CSR rationale, several members of the company stressed the importance of monastic education in Myanmar. As almost $90 \%$ of the population is Buddhist, monastic education is a source of national pride. Accordingly, 
Parami aims to support one third of monastic education across the country. None of these programs occurred in areas of active operations.

Sometimes, the personal ethics of one individual at a company are the key factor in CSR selections. A CSR manager for SMART, listed a string of philanthropies to which the company contributed. Its foundation, Ray of Hope, attends to a range of hardship tales that do not appear to have a specific logic. Aside from strong human resource policies to operate in a "green" fashion, it has initiated projects in Shan hills, provides hygiene in a variety of cities, supports a nunnery north of Yangon, as well as other self-described acts of "token philanthropy." Its CSR manager emphasized, "We want to help in any way we can" by gathering "true stories and true recommendations" to give out "assistance." A member from their CSR team explained: "I get stories and then I decide." In this case, CSR programs spanned a wide range of education and health programs, but only some were endorsed because particular stories appealed to the central coordinator.

Conversely, other CSR managers emphasized the business case for their CSR. An employee at MPRL articulated that the company will no longer adhere to community requests. Instead, the CSR team will implement thorough research to determine what community programs, if any, could be beneficial. Such programs must fit into the company agenda, and are constrained by allocated budgets. MPRL self describes its CSR as "a culture we create" and is working towards an environment that adheres to international standards. In doing this, the company is trying to change the perception of CSR from "just philanthropy" to become "Transformative CSR." As elaborated by MPRL staff, CSR and corporate activities are strategized and rationalized in the broader context of the company's goals. "Transformative CSR" is a way for a company to mitigate the impact of its activities, and to incorporate ethics and standards into everyday operations. ${ }^{33}$ Yet, such a turnaround does not happen in a short time span.

Global narratives and company philosophies are another significant driver. Companies such as Schlumberger and General Electric align their local CSR programs with their global development campaigns. Schlumberger, which has been operational in country for decades, implements CSR programs which are in line with its worldwide programs such as SEED and the Foundation for the Future program, an initiative which provides post-doctorate degrees for women around the world. This company does not do 'philanthropic gestures' per se, but rather focuses on training Myanmar individuals to be successful professionals through its Human Capital Development programs. Further, Schlumberger regards its R\&D funding as its greatest contribution. ${ }^{34}$ Increased technology and innovation is much needed, given a global shift towards using unconventional petroleum sources. Additionally, Schlumberger engages in multi-scale projects in country: it coordinates university career talks, donated Wi-Fi infrastructure to Yangon Technological University, implemented a safe driving program, hosted engineering seminaries, and provides emergency relief aid. Schlumberger and SMART readily invited me to participate in some of their external CSR projects.

General Electric only began regional operations in 2012, yet has committed seven million USD to CSR programs. All endeavors fit into their broader social objectives to actively change the "healthcare landscapes," enhance the "energy architecture," and promote the "human capacity" of Myanmar (General Electric, 2013). Among a myriad of CSR initiatives, GE focuses on maternal health, provides equipment and tools to major hospitals, invests in leadership training and rule of law, and has installed two aero-derivative gas turbines. Such development goals are not addressed by other companies. In an interview with General Electric's country director, he emphasized that providing electricity to Myanmar citizens is a primary social goal, and thus he works with different

\footnotetext{
32 If the donation of a school or hospital does not fit into the business rational of the company, MPRL will not oblige.

${ }^{33}$ The company does not have a history of Environmental Impact Assessments, Social Impact Assessments, or revenue transparency.

${ }^{34}$ Schlumberger spends 1.2 to 1.3 billion dollars a year on R\&D.
} 
ministries to realize this challenging objective. This is of particular significance given that roughly $30 \%$ of the population has access to electricity (U.S. Campaign for Burma, 2012).

Unlike operators of blocks, companies such as General Electric, Schlumberger, and SMART do not have a contractual obligation to a particular geography. Accordingly, they envision their CSR on a broader, nationwide scale. In addition to the locally placed programs that align with the company's global campaigns, oilfield service companies accomplish CSR in another fashion. ${ }^{35}$ Instead of a community program, several companies expressed that an important responsibility is to hire Myanmar nationals ( $80 \%$ in the case of Schlumberger, $91 \%$ for Halliburton, $100 \%$ for General Electric). They all emphasized that their strongest social commitment is to build up higher level education to lay a foundation for more Myanmar professionals. Accordingly, they provide professional training and assistance to local universities.

Companies can adhere to community requests, although community expectations and corporate intention can be misaligned. Such an impetus for CSR creation is thus contingent upon the local geography and communities. Companies such as Nobel $\mathrm{Oil}^{36}$ and $\mathrm{CNOOC}$ will provide $a d$ hoc assistance to those in their area of operation. Such impromptu social works range from hiring locals for "odd jobs" to providing short term medical assistance. In several interviews, company staff described the difficulty in wading through community "needs" and "wants."

Further, corporate understandings of responsibility and community relationships can be shaped by local NGO groups and activists. Total, Petronas, and PTTEP have engaged with ERI and local communities with respect to programs along the Yadana pipeline. Correspondingly, Daewoo and CNPC engage with Arakan Oil Watch and Shwe Gas Movement. On the other hand, some companies do not perform external CSR programs because they regard CSR as more of a duty to their company employees in the form of human resources.

Although MOGE is the operator for many blocks and has centralized control and management over profits and projects, MOGE does not engage in CSR other than to construct facilities per request of a community. MOGE is the centralizing and coordinating force for oil affiliated investments and social developments. Several sources mentioned that all company endeavors (ranging from pipeline construction to community program creation) must be run through MOGE. At times, companies partnered with MOGE will create CSR programs and push for higher standards of operation, but this is partner dependent and does not appear to be a common request.

External forces such as internationally acclaimed politicians and company stakeholders also influence corporate activity. Aung San Suu Kyi and Hillary Clinton's plea for inclusive and responsible growth is a fundamental call for corporations to not only enact programs of social responsibility but also to structure business endeavors in a sustainable manner. Until very recently, governments and corporations collectively divested in Myanmar in reaction to alleged corporate malpractices. Total and Chevron were harshly criticized in their home nations. Public activism culminated in years of litigation. Yet, the corporate "shaming" continues. Epstein \& Barclay examined the cognitive dissonance in inter-state "green shaming" and how such environmental shaming can be used as a foreign policy tactic (Epstein \& Barclay, 2013).

In addition to pressure from public figures, company stakeholders can encourage changes in corporate activity. A recent copy of Chevron's 2014 Proxy Statement (available online) includes multiple stakeholder requests for Chevron to properly address environmental impact and humanitarian violence in association with the company's conduct. Proxy statements are required company statements when soliciting shareholder votes. The stakeholders described Chevron's current country selection as "opaque" and commented that Chevron does business in countries with "controversial human rights records" (Chevron, 2014). Although the directors responded to such criticisms at the bottom of each page with the comment "[y]our Board unanimously

\footnotetext{
${ }^{35}$ Most oilfield companies emphasized the importance of R\&D investments as a responsibility to the entire world. Although Halliburton and Weatherford do have global CSR initiatives, they do not yet have external CSR programs in Myanmar.

${ }^{36}$ However, Nobel Oil, does not create extensive community CSR programs, partly because there is no community to speak of in the jungle.
} 
recommends that you vote AGAINST this proposal," the Proxy Statement is nevertheless significant as it voices concerns that had been entirely absent from Chevron's public relationship with Myanmar.

In her study of mining in Indonesia, Welker learned that Western companies, as opposed to their Asian counterparts, were more often targeted by NGOs and activists for corporate reform and CSR creation (Welker, 2014). This insight holds true in the case of EarthRights' activism against Total and Chevron. ERI staff remarked that they specifically targeted Total and Unocal (now Chevron), rather than file charges against the Asian partners PTTEP and MOGE, because they assumed that the two Western companies would be more likely to respond to the NGO's calls to alter corporate behavior. Total has responded to most of ERI's campaigns. Although Chevron has no online documentation, my interviewers suggest it continues to be responsive to NGO requests.

\subsection{Uneven Obligations in the Oilfield}

There are several uneven expectations and obligations directed at companies in this sector. First, it is the operator that is expected to create and sustain community CSR programs, despite the fact that there are dozens of companies involved in any one operation. Contractors and subcontractors (e.g. oilfield service companies) are not expected to participate in this initiative. Second, although operators of onshore and offshore projects maintain that partners contribute funding to all CSR, there does not appear to be a systematic method for this. Third, certain corporations experience more public scrutiny than others.

\subsubsection{The Operators}

Project contractors and sub-contractors are not expected to create community programs, as they are not operators. I found this a surprising revelation, having initially assumed that all constituents of a project would engage in at least some sort of CSR. These companies are integral components of resource extraction in Myanmar, providing services ranging from drilling the pits, to exploring for petroleum, and to housekeeping and catering services for workers on rigs. However, some oilfield service companies such as Smart and Schlumberger actively engage in CSR. Their community programs are found in random villages or are embedded HR strategies within a respective company.

Although many operators emphasized they received funding from their partners to enact CSR, the responsibility to organize, coordinate and sustain CSR programs falls upon the operator. Managers and other corporate staff, stressing the importance of development initiatives, mentioned their companies would donate ad hoc to select programs. Sometimes this meant they donated to a partner's program, while other times this meant that they would donate to unaffiliated companies with which they do not conduct business, but they found the CSR initiative impressive. Although this sounds like an excellent proposal, my interview with Global Witness expressed concerns that such donations to other companies' CSR programs would not leave a transparent money trail.

\subsubsection{No Media for the "Cowboys"}

In the international spot light, large scale operators bear the brunt of criticisms as indicated by Du and Vieira (Du \& Vieira, 2012). They found that larger oil corporations such as BP and Chevron face harsher criticism relative to smaller oil corporations, a trend I also discovered in my research. Total, Chevron, Daewoo, and large Chinese companies bear the brunt of social and environmental criticism. Organizations such as EarthRights and Arakan Oil Watch have launched detailed investigations to the Yadana and Shwe Projects, respectively. However, there are no detailed accounts of the less well known onshore and offshore operators or contractors.

Smaller and less well known "cowboy companies," escape the attention of the media, as described by the director of a major oilfield service company. This director criticized the vast number of such "cowboy companies" whose disregard of operational standards has usually remained out of the international limelight. In particular, he cited the smaller Indian, Russian, 
Korean, and Chinese companies. During our conversation, he emphasized that, "everyone is watching" so Western companies must adhere to stakeholder requests, and that such companies must publicize all activities. Although these comments came from an oilfield service director, it is generally contractors and subcontractors that evade international media and NGO scrutiny.

\subsubsection{Western Targets}

Further, activist organizations usually target Western corporations, such as Total and Chevron, over their Asian counter parts, such as PTTEP and MOGE. This is evident from the series of legal cases launched against Total and Chevron by EarthRights, as well as from the list of publications detailing alleged corporate malpractices. ERI staff remarked that they specifically targeted Total and Unocal (now Chevron), rather than file charges against the Asian partners PTTEP and MOGE, because they assumed that the two Western companies would be more likely to respond to the NGO's calls to alter corporate behavior. Although EarthRights includes Petronas, PTTEP, and MOGE in their analysis, most of their publication titles are aimed at changing the corporate activities of the Western companies. Titles such as Total Impact, Getting It Wrong, The True Cost of Chevron, and The Human Cost of Energy (think Chevron's slogan, "Human Energy") are retorts to corporate slogans or publications. However, this trend is not always the case. As for the Shwe Project, Arakan Oil Watch and the Shwe Gas Movement have detailed information about the major company partners (South Korean, Indian, and Chinese companies). These organizations have created a series of publications similar to those of EarthRights. In both cases, the contractors and subcontractors are not usually mentioned.

\section{Conclusions}

\subsection{Concluding the Architects' Logic}

When examining the geography of projects, it is evident that offshore and onshore operators and contractors, engage with communities (at some scale) for the purposes of welfare and philanthropy. During the course of my fieldwork, I was never given a precise definition for what does and does not constitute the surrounding 'communities,' or how far (in terms of geographic distance) their zone of responsibility extends. For the most part, many programs appear to be randomly selected and administrated. The vicinity of responsibility appears to be entirely up for interpretation to individual operators. Most participants answered in vague language, and indicated that the geographic span of assumed obligation is subject to change over the years and is dependent on the company's leadership.

The internal logic and global forces of corporate entities further determine how CSR can be shaped. Taking into consideration all of the specific company rationales, it becomes evident that Western and Burmese corporations tend to be more engaged in the CSR effort. Pressure from respective national countries can encourage a greater adherence to regulatory standards and encourages a more active role in external CSR programs. The court cases launched against Total and Chevron, in Belgium and the U.S. respectively, catapulted their corporate activities to the public and encouraged a working relationship with NGOs and local communities. Newcomers such as General Electric and old-timers such as Schlumberger align programs in Myanmar with their global initiatives. Although disparate in CSR implementation, Burmese companies such as MPRL, Smart Technical, and Parami organize CSR efforts in individualized manners in accordance with a set of local and personal values. In addition to external forces, the individual corporate philosophy shapes the particular direction of social programs.

Asian companies, with the notable exception of Petronas, have created less extensive programs to date. Both Asian and Eurasian companies usually respond to particular community requests and regard CSR as philanthropic constructions instead of embedded corporate strategies. Further, there does not appear to be a system to publicize these actions. However, this is not entirely unsurprising. An analyst from the Business and Human Rights Centre mentioned that Asian corporations do not have a history of publicizing their corporate activities and do not see the need 
to respond to media requests. This is not to say that these companies do not create programs or adhere to standards, but that there is less of a precedent to engage with the public. This has, in part, resulted in the stereotype that Chinese and other Asian companies are "secretive," "shady," and "elusive." In response, an engineer from an Asian company stated that "sincere efforts need no headlines."

A company's operational scope further complicates the CSR issue. In short, oilfield service companies (drilling, security, catering, etc.) are all vital to petroleum projects. Yet, they are rarely mentioned as responsible agents. Nor are they the usual targets of NGOs. Less well known corporations can escape the attention of the media, and they do not appear to be pressured by stakeholders, nor are they on the public forefront. There are concerns with methods of CSR funding by project partners, and there is an uneven level of scrutiny by the media and activist organizations. By incorporating contractors and partners into the realm of responsibility, this further expands but also convolutes the boundaries of responsibility.

\subsection{Criticisms \& Challenges}

Members from non-profit and research organizations expressed that CSR should incorporate not only all components of corporate accountability, but also have social programs that go beyond philanthropy. Accordingly in an ideal world, true corporate accountability would include full economic disclosure, such as revenue transparency and public information about beneficial ownership, complete disclosure of environmental and social impacts in the form of published EIAs and $\mathrm{SIAs}^{37}$, and would integrate operation standards of "doing no harm." This would include a strict legal component; however, this is ambitious in all country settings, even countries with strict standards. It would further include robust HR measures of equal and fair pay and compensation for company workers.

There is also a temporal aspect to this category. According to the directors of two different nonprofits, none of the recently operational companies have enough of a track record to warrant any praise. Although time will tell, companies including General Electric and BG Group ${ }^{38}$ were mentioned in numerous interviews as hopeful candidates for such type of responsible investment. At the moment, most CSR praise is reserved for Total and Petronas' programs, possibly in part because they have been involved with communities for over 20 years.

One researcher I interviewed believed that companies needed to take into account national problems rather than focus on select community grievances. He disregarded the corporate outline from Business and Human Rights Resource Centre as the way to move onwards. Instead, he maintained there is a need for "deep and thorough" understanding of legal accountability and Myanmar's contradicting laws. The lack of regulation implementations and challenges from the "leftover dictatorship bureaucracy" must be addressed by corporations, in addition to addressing issues of "compensations and systematic corruption." State taxes should be paid (and closely monitored) so that the government may build up and support its own communities. Addressing labour rights, including fair, equal, and timely pay, is also a key component. He concluded there is "promise" of such a system from those recently awarded blocks, but others have a more cautionary approach to these corporate entities given that the gas reserves are still unknown. All of these sentiments were echoed in my interviews with personnel from the World Bank, Global Witness, and Revenue Transparency. Two researchers maintained that, given the landscape of problems, companies have a responsibility not to invest until systematic issues (such as land ownership, tax allocations) are properly addressed by the state. Relatedly, the question posed by Holliday, "can profits and principles be secured in tandem?" in The Yadana Syndrome, obviously does not have a clear answer (Holliday, 2005).

I conducted an informal interview with a professor who focuses on transnational conflict, corporations, and the development of human rights in Myanmar. He mused that much of the CSR in Myanmar is little more than a public front which he likened to "Public Social Responsibility." It

37 Myanmar published its ESIA regulations in 2015, thus after the timeframe of this report.

${ }^{38}$ BG was acquired by Shell after the timeframe of this report. 
can be difficult, if not impossible, to verify the proclamations of CSR. Boycotting a select oil company for moral reasons, he elaborated, does not work in the same fashion as boycotting a particular clothing or electronics brand. This is for two reasons. First, our great dependency on oil and gas as an energy source and a building block for a range of needs (medical supplies, soaps, battery cases, fertilizers, synthetic rubber...) hampers any comprehensive rejection of a particular corporation. Secondly, oil and gas products are pooled by corporations. Thus, boycotting one company does not necessarily affect the targeted corporation. He reasoned this is why the underlying structures of oil extraction and transport have not been changed despite the activism against petroleum extraction, production, and transportation. In the meantime, companies have embarked on "extreme PR adventures... and then CSR."

The director of an environmental NGO emphasized the need for a "serious conversation" about CSR instead of a "shouting match between ultra-moral eco warriors against super evil oil managers, with those of a less absolutist stance silenced in between." Activists such as Arakan Oil Watch's director firmly believe that there should be absolutely no international corporate engagement until corruption and rights abuses are addressed. However, given the momentum of the petroleum industry, this encourages an absolutist-only platform for discussion on investment.

\subsection{Implications}

This paper explores the assumed spheres of corporate responsibility, but exact delineations of corporate obligations continue to remain elusive. Ultimately, the geography of operations, the national origin of a company, and the type of company operations can be significant factors in shaping a corporation's understanding of 'responsibility' in Myanmar. Such assumed spheres of responsibility, in a complex and unregulated setting, is simultaneously amorphous and quantifiable.

As for geography, offshore operators have comprehensible geographic relationships for their community programs, while onshore operators and contractors do not. These rationales are in line with the encouragement and discouragement from the Myanmar government. Regarding development goals, company rationales for CSR have been shaped by a number of factors and forces. These range from pressure of activist organizations and international actors, the Myanmar government, to the personal ethics of a company individual. This generalization can begin to answer the questions about what is means to be responsible, and how is this created and sustained? In short, this understanding of responsibility is layered with complexity.

The companies I interviewed unanimously expressed their "obligation" to "give back" and to "do the right thing." However, deciding where and how to "give back" is a multi-dimensional process filled with a complex array of justifications, some with seemingly little reason. I have demonstrated that petroleum operations radically change local environments, but they also have the potential to create new zones of development and welfare. The contours of responsibility are complex and malleable, but have elaborate rationalizations in this Myanmar context.

Although this research examines the geographic span and materialization of CSR in the petroleum sector, these findings can be applied beyond Myanmar and oil-funded development projects. CSR is far more complex than mere acts of corporate charity, or PR. Rather, it is the contemporary solution to global corporate malpractice when extracting terrestrial and marine resources. Yet, it is still undefined. It is a conventional method for enacting and demonstrating 'responsibility' to society as a whole. However, it is still poorly understood and unevenly applied. Understanding how companies enact 'responsibility' should be a focus for research, rather than be dismissed as inconsequential and empty. Because, by looking at CSR, one is not merely examining a development project or an environmental standard. CSR fits into the broader context of the consequences arising from rapid globalization, the commodification of development, the performance of corporate morality, and the financial investments in what are referred to as 'extreme contexts' and 'failed states.'

\section{Acknowledgement}


Kind thanks to my UH advisor and mentors, Reece Jones, Krisna Suryanata, and Johnathan Padwe; my Myanmar family including Aunty Bo, Uncle Myo, Nida, Kirt, David, Rosie, Lou, Yu Yu, Georgi, \& Aung Soe Min; and mahalo to my 'ohana including Aurora, Ali, Todd, Allie, Mary, Dylan, Micah, \& Keith; and to my parents, Eric, Omi, and Pa for support and encouragement.

\section{References}

Arakan Oil Watch. (2012). Burma's Resource Curse: The case for revenue transparency in the oil and gas sector. Thailand: Arakan Oil Watch.

Aye Myat. (2015, January). Myanmar Business Today. Retrieved from Myanmar to Promote International Energy Cooperation: https://goo.gl/dpNVJi

Barkan, J. (2013). Corporate Sovereignty: Law and Government under Capitalism. Minneapolis: University of Minnesota Press.

Black, N. (2009). Blood Money: A Grounded Theory of Corporate Citizenship Myanmar (Burma) as a Case in Point. University of Waikato: A thesis submitted in fulfilment of the requirements.

Bridge, G., \& Le Billon, P. (2013). Oil. Cambridge: Polity Press.

Chevron. (2014). Notice of the 2014 Annual Meeting and 2014 Proxy Statement. Chevron.

CNPC. (2012). 2012 Corporate Social Responsibility Report. China National Petroleum Corporation.

Dellinger, L. (n.d.). Corporate Social Responsibility: A multifaceted Tool to Avoid Alien Tort Claims Act Litigation while simultaneously building a better business reputation. California Western International Law Journal, 40.

Doe v. Unocal Case History. (2012). Retrieved from EarthRights International: http://www.earthrights.org/legal/doe-v-unocal-case-history

Du, S., \& Vieira, E. (2012). Striving for Legitimacy Through Corporate Social Responsibility: Insights from Oil Companies. Journal of Business Ethics.

EarthRights. (2004). Another Yadana: The Shwe Natural Gas Pipeline Project (Burma-Bangladesh-India). EarthRights International.

Epstein, C., \& Barclay, K. (2013). Shaming to 'green': Australia-Japan relations and whales and tuna compared. International Relations of the Asia-Pacific, 95-123.

Ferguson, J. (2012). The Structures of Resbonsibility. Ethnography.

General Electric. (2013, July). GE Assistance for Myanmar. Retrieved from General Electric: http://3blmedia.com/News/CSR/GE-Assistance-Myanmar

Gilberthorpe, E., \& Banks, G. (2012). Development on whose terms? CSR discourse and social realities in Papua New Guinea's extractive industries sector. Resource Policy.

Global Finance. (2015, July 22). Myanmar GDP and Economic Data. Retrieved from https://www.gfmag.com/global-data/country-data/myanmar-gdp-country-report

Godfrey, P. C. (2009). The relationship between corporate social responsibility and share holder value: An empirical test of the risk managment hypothesis. Strategic Management Jounral, $30(4), 425-445$.

Haalboom, B. (2012). The intersection of corporate social responsibility guidelines and indigenous rights: Examining neoliberal governance of a proposed mining project in Suriname. Geoforum, 43(5), 969-979

Holliday, I. (2005). The Yadana Syndrome? Big Oil and Principles of Corporate Engagement. Asian Journal of Political Science, Volume 2.

Lall, V. (2012, October 22). Why CSR matters in new Myanmar. Retrieved from The Myanmar Times: https://goo.gl/TVRTOP

Lee, M.-D. P. (2008). A review of the theories of corporate social responsibility: Its evolutionary path and the road ahead. International Journal of Management Reviews.

Mitchell, T. (2013). Carbon Democracy: Political Power in the Age of Oil. London: Verso.

Myanmar Centre for Responsible Business. (2014). Responsible Business, CSR and oil/gas and power contracts in Myanmar. Yangon: MCRB.

Myanmar Profile. (2014). Retrieved from BBC News: https://goo.gl/RSOzq1 
Nebehay, S. (n.d.). Suu Kyi says Myanmar needs responsible investment. Retrieved from http://www.reuters.com/article/2012/06/14/us-myanmar-swiss-suukyi-idUSBRE85C1NA201 20614

Oxford Business Group. (2014). The Report: Myanmar . Oxford Business Group.

Peluso, N., \& Watts, M. (2001). Violent Environments. Ithica: Cornell University.

Ra, S. T., \& Griffin, B. (2014). Why CSR is the right tool to break into Myanmar markets. Retrieved from https://goo.gl/jhmRck

Rajak, D. (2011). In Good Company: An Anatomy of Corporate Social Responsibility. Stanford.

Shamir, R. (2010). Capitalism, governance, and authority: The case of corporate social responsibiliy. Annual Review of Law and Social Science, 531-553.

Temphairojana, P. (2013, October 29). Despite low rating, Myanmar business climate improving World Bank. Retrieved from Reuters: https://goo.gl/5tsK83

Transparency International. (2014). Corruption Perceptions Index. Retrieved from Transparency International: http://www.transparency.org/cpi2010/results

U.S. Campaign for Burma. (2012, January 7). Day \#: Shwe Gas Movement. Retrieved from U.S. Campaign for Burma: https://goo.gl/A7JiOm

Welker, M. (2014). Enacting the Corporation.

World Bank. (2014, February 23). Myanmar Country Overview. Retrieved from World Bank: http://www.worldbank.org/en/country/myanmar/overview 